\title{
Peripheral resistance to thyroid hormones
}

INSERM

\section{Source}

INSERM. (1999). Orphanet: an online rare disease and orphan drug data base. Peripheral resistance to thyroid hormones. ORPHA:97927

Peripheral resistance to thyroid hormones may be a cause of permanent congenital hypothyroidism (see this term), a permanent thyroid hormone deficiency that is present from birth. 